\title{
Verbal abuse of nurses by physicians in a private sector setting
}

\author{
E Joubert, MCur Graduate \\ University of Pretoria
}

A du Rand, MCur Nursing Management

Senior Lecturer, Department of Nursing Science, University of Pretoria

$\mathrm{N}$ van Wyk, PhD Nursing Science

Head, Department of Nursing Science, University of Pretoria

\section{Keywords:}

nurse-physician relationship, verbal abuse, violence, private health care

\section{Correspondence address:}

Prof Neltjie van Wyk

Department of Nursing Science

University of Pretoria

PO Box 667

Pretoria

0001

Tel: (012) 3541980

Cell: 0827761649

E-mail: nvanwyk@medic.up.ac.za

\section{Abstract: Curationis 28(3): $39-46$}

The aim of the study was to determine whether physicians in a private sector setting verbally abuse nurses, and to what extent. A review of the literature showed that verbal abuse by physicians accounts for the highest incidence of aggression towards nurses in health care, and that it is strongly related to turnover rates. It has also been reported in recent studies that within the context of verbally abusive episodes, patient care, work productivity, morale and job satisfaction have been negatively affected.

Of the 120 questionnaires that were distributed among registered and enrolled nurses, 83 were returned in time to be used, which was a response rate of $69 \%$. This response rate is consistent with previous studies and is exactly the same as for a study that was done in Turkey (Uzun, 2003:81). The questionnaire used was one that has been adapted from the Verbal Abuse Scale developed by Manderino and Berkey (1997:50) and the Revised Conflict Tactics Scale (CTS 2) as described by Little (1999:24), and was in the form of a 4-point Likert-scale with one open ended question.

The results showed that $79 \%$ of the nurses admitted that verbal abuse was taking place. Forms of direct verbal abuse included $81 \%$ that felt they were criticised unjustly, $76 \%$ that were screamed at in front of others, and $81 \%$ that felt physicians vented their frustration on them.

The results obtained in the study were consistent with previous studies done elsewhere and it indicated that nurses still experience high levels of verbal abuse in the workplace.

\section{Opsomming}

Die doel van die studie was om te bepaal of geneeshere in ' $n$ privaat sektor opset verpleegkundiges verbaal mishandel, en tot watter mate. 'n Oorsig van die literatuur het getoon dat verbale mishandeling deur geneeshere verantwoordelik is vir die hoogste insidensie van aggressie teenoor verpleegkundiges in gesondheidsorg, en dat dit nou verwant is aan die omset-syfer. Dit is ook in onlangse studies gerapporteer dat binne die konteks van verbale beledigings-episodes, pasiëntsorg, werksproduktiwiteit, moreel en werksbevrediging negatief beïnvloed word.

Van die 120 vraelyste wat aan geregistreerde en ingeskrewe verpleegkundiges uitgedeel is, is 83 betyds teruggestuur om te gebruik, wat ' $n$ respons-syfer van $69 \%$ was. Hierdie respons-syfer is in ooreenstemming met vorige studies en is presies dieselfde as die vir ' $\mathrm{n}$ studie wat in Turkye gedoen is (Uzun, 2003:81). Die vraelys wat gebruik is, was een wat aangepas is van die "Verbal Abuse Scale" wat deur Manderino en Berkey (1997:50) ontwikkel is en die "Revised Conflict Tactics Scale (CTS 2)" soos beskryf deur Little (1999:24), en was in die vorm van 'n 4-punt Likert-skaal met een oop-einde vraag. 
Die resultate het getoon dat $79 \%$ van die verpleegkundiges erken het dat verbale mishandeling plaasvind. Die voorkoms van direkte verbale mishandeling het getoon dat $81 \%$ van die respondente gevoel het dat hulle onnodig gekritiseer is; daar is op $76 \%$ geskree voor ander en $81 \%$ het gevoel dat geneeshere hul frustrasies op hulle uithaal.

Die resultate wat in die studie verkry is stem ooreen met vorige studies wat elders gedoen is en dit het aangedui dat verpleegkundiges steeds hoë vlakke van verbale mishandeling in die werkplek ervaar.

\section{Introduction}

Verbal abuse is an occupational hazard and the prevalence of it against nurses is of great concern, especially when comparisons are drawn with other professionals (International Council of Nurses, 2000:5). Among health personnel, the nursing staff are at the most risk of violence. Verbal abuse is typically found in relationships of unequal power and is a factor in maintaining the disproportional amount of power of one individual in the relationship (Manderino \& Berkey, 1997:48). In the private health care sector, hospital management is obliged to favour physicians, as a withdrawal of their patients will lead to a decrease in the income of the hospital. This leaves the nurses highly vulnerable and creates relationships of unequal power.

\section{Background to the study}

According to Diaz and McMillan (1991:98) the role-conflict between physicians and nurses arises from a difference in how they view the nursing role. either as a traditional repressive/ nurturing role responsive to others' needs or, as the more recently defined instrumental/agentive role, through which scientific knowledge is used to make rational decisions. The latter role has historically been delegated solely to physicians.

The differences in the interpretation of the role of the nurse contributes to misunderstanding, and unfortunately, also to the verbal abuse of nurses. It can take on different forms ranging from accusing nurses of mistakes that they did not make, to venting their frustrations on them when something goes wrong, or to actually screaming at them and calling them names.
The verbal abuse of nurses in South Africa is a serious problem that is increasing. In 2002 Geyer and Zondagh (2002:32) stated that: "DENOSA (Democratic Nurses Organization of South Africa) received several complaints about medical practitioners' unacceptable conduct towards nurses over the past few months. Nurses are verbally abused, belittled and the practitioners imply that nurses are stupid and incompetent in front of the patients, visitors and other staff."

Although verbal abuse of nurses by physicians is a worldwide trend (International Council of Nurses, 2000:5), the occurrence of verbal abuse in South Africa can be attributed to the occurrence of violence in the society. According to Kreitzer, Wright, Hamlin, Towey, Marko and Disch (1997:35) violence in the workplace usually reflects the violence in the society.

\section{Problem statement}

Verbal abuse strongly relates to the turnover rate of nurses (Cox, 199l(b):66). It thus inevitably intensifies the stress placed on an often already short-staffed health care unit (International Council of Nurses, 2000:8) with detrimental effects on the quality of care rendered to patients.

In the private health care sector the hospital management try and negotiate with as many as possible physicians to make use of their facilities for the care of their patients. The physicians are thus in a favourable position as they determine the income of the hospital. Hospital management at all times tries to meet all the needs of the physicians in order to ensure that they will continue to admit patients to the hospital. It is expected of the nurses as employees of the hospital management to support the management in meeting the needs of physicians. This attitude leaves nurses prone to unreasonable demands by physicians.

\section{Aim of the research}

The aim of the research was to determine whether nurses were being verbally abused by physicians in a selected private sector setting, and to what extent.

\section{Concept clarification}

For the purpose of this research, verbal abuse is defined as any communication a person perceives to be a harsh, condemnatory attack upon her or himself, professionally or personally (Cox, $1991(a): 32$ ), while the International Council of Nurses (2002: 4) described abuse as behaviours that humiliate, degrade or otherwise indicate a lack of respect for the dignity and worth of an individual.

\section{Significance of the study}

Nursing managers can be made aware of the incidence of verbal abuse of their staff through the findings of this research and encourage them not to minimize incidents of verbal abuse and quietly accept them. By addressing the problem, the stress caused will be decreased with resulting job satisfaction and retention of staff.

\section{Research design and Methodology}

A descriptive contextual design was used. The research population was comprised of all the registered and enrolled nurses working in the specific private sector hospital. All the nurses who were on duty on the day of distribution of the questionnaires were invited to participate in the research. It included registered and enrolled nurses from all the wards, intensive care units and operating rooms. Ninety registered nurses and thirty enrolled nurses were on duty on that specific day.

A structured questionnaire, adapted from the Verbal Abuse Scale (VAS) developed by Manderino and Berkey (1997:50) and the Revised Conflict Tactics Scale (CTS2) as described by Little (1999:24), was used. The VAS is a 65 item self-report questionnaire which defines 11 different forms of verbal abuse, while the CTS 2 is a 15 item questionnaire, which was originally developed by Strauss, Hamby, Boney-McCoy and Sugarman (1996). The VAS has an internal consistency of Cronbach's alpha coefficient of 0.67 to 0.95 (Cook et al. 2001:322). The CTS2 has been used in numerous community studies of violence and was found to have excellent internal consistency and construct validity (Little 1994: 24). A 4point Likert-Scale was used in the questionnaire with only one question requesting a descriptive answer.

A meeting was arranged in each ward with the registered and enrolled nurses on the day of the data collection in order to explain the research to them and to invite them to participate. Those who agreed 
and indicated that they wanted to participate were given the questionnaire with a covering letter explaining that by completing the questionnaire informed consent had been obtained. All respondents were also provided with an envelope labelled with the name of the primary researcher. They were requested to complete the questionnaire and to place it in a box provided in the office of the secretary of the Nursing Service Manager and in the office of the Nursing Manager of the operating room. From there, the questionnaires were collected on a specific date by the researcher.

\section{Ethical considerations}

Permission to carry out the study was obtained from the Ethical Committee of the Faculty of Health Sciences of the University of Pretoria and from the relevant authorities of the private hospital.

As the covering letter handed to those who were willing to participate had explained that completion of the questionnaire constituted informed consent, their anonymity was ensured. They were also asked not to write their names anywhere on the questionnaire, or provide any information that could lead to them being identified. The participants were also assured that their responses would be regarded as confidential.

\section{Reliability and validity}

As the instrument used was adapted from other instruments, a pilot study was earlier done, consisting of 2 enrolled and 2 registered nurses. The results indicated that the questionnaire did not need any changes and was therefore valid and reliable. The nurses were not further used in the main study.

A literature study about the topic had been done to ensure that an instrument is used that will ensure the validity of the findings. Instruments that were used by other researchers and have been proven to provide valid data were adapted for the unique circumstances and the context in which the research had been carried out.

\section{Data analysis and findings}

Descriptive statistics with regard to frequencies and percentages were calculated for all variables on the structured questionnaire. Answers to the open question were analysed separately by the primary researcher. Recurrent topics were identified and described.

\section{Profile of the respondents}

Of the 90 registered nurses and 30 enrolled nurses who were on duty on that day, $14(47 \%)$ enrolled nurses and 69 (77\%) registered nurses returned completed question-naires. A response rate of $69 \%$ has thus been achieved, exactly the same as in a study on the perceptions and experiences of nurses in clinical settings that had been done in Turkey (Uzun, 2003:81). Persons younger than 40 years of age represented $61 \%$ of the respondents. With the largest group being between 30 and 39 years old, they constituted $37 \%$ of the sample. Only $15 \%$ of the respondents were 50 years and older. The majority of respondents, namely 50 persons $(61 \%)$, were married.

The majority of the respondents $(56 \%)$ were in the specific posts for less than 10 years at the time of the research. Only 21 persons $(26 \%)$ were employed for 15 years and longer.

The complete sample of 69 registered nurses held qualifications, registered with the SA Nursing Council, in General Nursing Science, while 53 (77\%) also had qualifications in Midwifery, $14(20 \%)$ in Operating Room Nursing Science, 38 (55\%) in Psychiatric Nursing Science and Community Nursing Science, 19 (28\%) in Intensive Care Nursing Science and $2(3 \%)$ in Trauma Nursing. The 14 enrolled nurses had qualifications in fundamental and general nursing.

Nursing is viewed as a female profession in the South African context. It is also reflected in the composition of the respondents of this study as only 3 male nurses were involved. As nursing is viewed as a female dominated profession in South Africa, and physicians are still mostly male, this could influence the interpersonal relationships.

\section{Nurses as victims of verbal abuse}

Of the 82 respondents who answered this question, $49(60 \%)$ reported that verbal abuse of nurses by physicians takes place sometimes, while $15(18 \%)$ were of the opinion that it happens often (refer to: Table 1). Seventeen respondents $(21 \%)$ were not aware of such incidents. By far the majority of the respondents agreed that verbal abuse of nurses by physicians does take place.

In the study that had been done in Turkey by Uzun (2003:81) 87\% of the respondents indicated that they had experienced verbal abuse in the 12 months that preceded the study. Although the incidence in the South African study is much lower, the mere fact that it takes place is unacceptable. Verbal abuse influences the relationship between physicians and nurses negatively (Geyer \& Zondagh: 2003:32). This may explain why nurses in a study done by Begany (1995:32) reported that nurses felt that physicians did not respect them.

As indicated earlier, verbal abuse has been defined as any communication perceived as a harsh, condemnatory attack. One can therefore divide it into two groups, namely direct verbal abuse, and indirect verbal abuse. Last named implying that non-verbal communication (body-language or behaving as if the nurse does not exist) would also be a form of verbal abuse.

Tabel 1: Occurrence of verbal abuse

\begin{tabular}{|l|ll|}
\hline Occurrence & \multicolumn{2}{|c|}{ Frequency } \\
\hline Never & 17 & $(21 \%)$ \\
\hline Sometimes & 49 & $(60 \%)$ \\
\hline Often & 15 & $(18 \%)$ \\
\hline Always & 1 & $(1 \%)$ \\
\hline $\mathrm{N}=82$ & & $(100 \%)$ \\
\hline
\end{tabular}

\section{Direct verbal abuse}

The occurrence of 3 types of direct verbal abuse were determined in this research, namely: being criticised without a reason; being sworn at or insulted; and screamed or shouted at in front of other people. Not all the respondents answered this question (refer to: Figure 1).

Of the 81 respondents who answered the question on being criticised unjustly, $59 \%$ indicated that it happens sometimes, while $21 \%$ indicated that it often happens. It seems as if nurses are less frequently insulted, as $50 \%$ of the 76 respondents who answered this question reported that it does not take place at all, while $38 \%$ reported that it happens sometimes and $11 \%$ that it often happens. Unfortunately, being screamed at in front of other persons seems to happen quite often as $20 \%$ of the 79 respondents who answered 


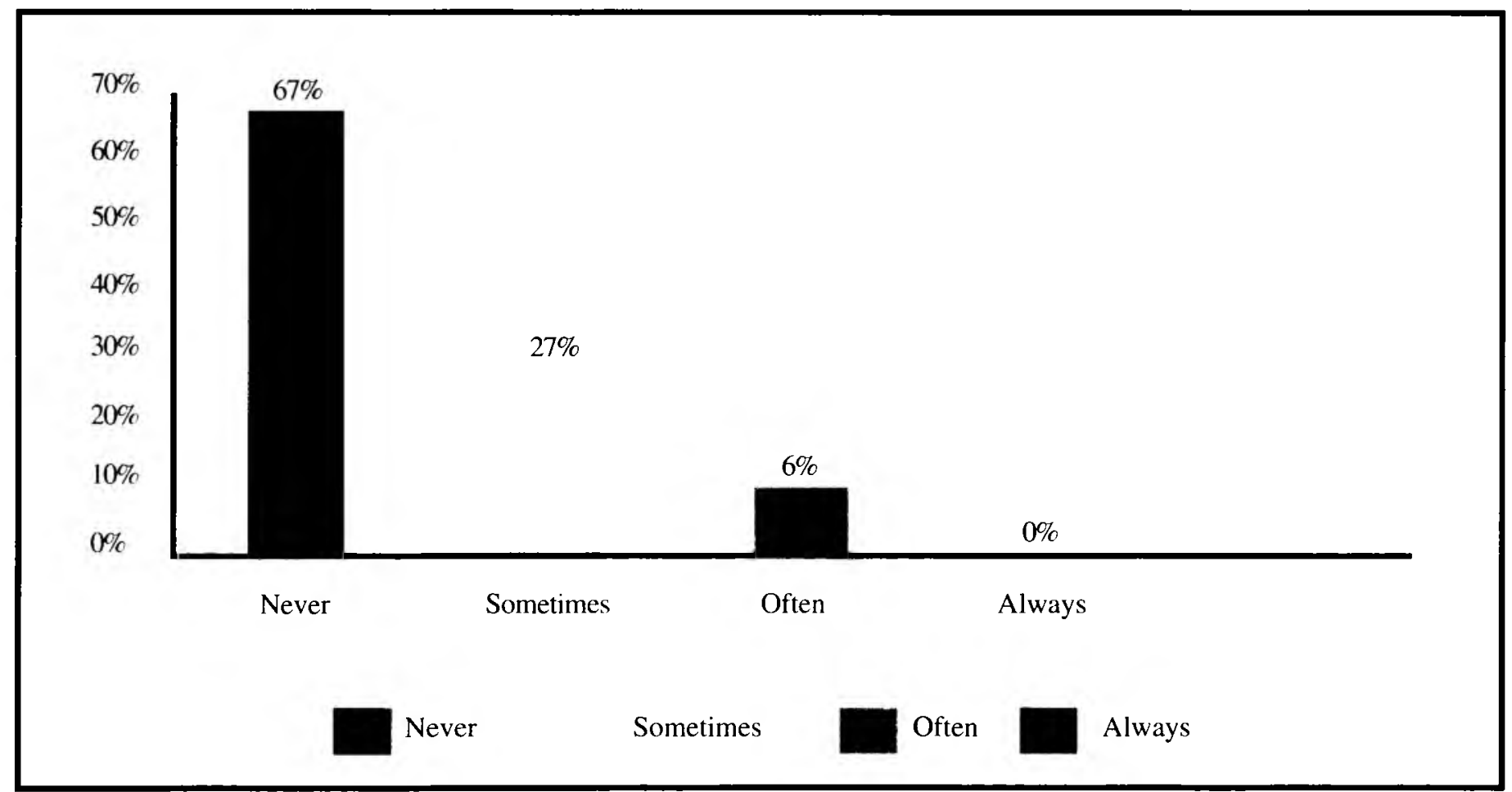

who answered the question reported that it happened either 'sometimes' or 'often'. An additional 5\% are, according to them, always victims of it. Of the 80 respondents who answered the question about intimidation, $54 \%$ were convinced that it happens at times, often or even on a continuous basis.

According to the perception of Begany (1995:32) physicians often blame nurses due to their perception of nurses as being 'know-nothings' who are inferior to them and who should take the blame for every problem.

\section{Forms of spitefulness \\ experienced by the respondents}

The majority of the respondents $(67 \%)$ who answered the question felt that according to their experience, physicians never said bad things to the nurses just to spite them (refer to: Figure 3). It seems as if it is not common practice that physicians verbally abuse nurses just for the sake of abusing them.

\section{Forms of meanness experienced by the respondents:}

Two aspects, namely suggestive jokes, and that of physicians deliberately misunderstanding nurses when they take part in discussions, were investigated. Of the 76 respondents who answered this question, $37 \%$ had been victims of suggestive jokes made by physicians. This is considered to be a less aggressive form of verbal abuse and nurses working in operating theatres are often exposed to it. Operating theatre nurses have to endure what Watson (2002:228) describes as lewd jokes and comments about co-workers' anatomies. It is also in this atmosphere that physicians sometimes deliberately misunderstand nurses when they say something innocently. It is done in order to contribute to the jokes that are exchanged. In this study $44 \%$ of the 77 respondents who responded indicated that they have experienced the latter (refer to: Figure 4).

The relatively small percentage in this instance compared to the percentages of respondents who experienced other types of verbal abuse, can possibly be attributed to the fact that this type of abuse is more often experienced in operating theatre rooms whereas all the nurses who were on duty in all units of the hospital were invited to take part in the research.

\section{Forms of indirect verbal abuse}

This form of verbal abuse relates more to a non-verbal form of abuse, as it is not so much what is being said than the bodylanguage or behaviour. It is as if the nurse does not matter and does not exist, that embarrasses the nurses.

\section{Four presentations of indirect verbal abuse have been studied}

Speaking to the nurse via other people; addressing the nurses only when it is absolutely necessary; making nurses feel bad; and making nurses feel responsible for other people's mistakes. It happened to nearly half of the respondents $(46 \%)$ who responded to this question that physicians have. in the past spoken to them via other people, which they experienced as extremely degrading.

By far the majority of the respondents, namely $83 \%$, indicated that a physician made them feel bad, while $82 \%$ felt that they were only spoken to when necessary, and $76 \%$ felt that they were made to feel responsible for other people's mistakes (refer to: Figure 5).

\section{Being overlooked by the physicians}

The majority of the respondents $(74 \%)$ felt that, in the past, physicians ignored them as if they did not exist or were not worthy of being noticed. This usually happened after disagreements. The respondents also reported that physicians in some cases $154 \%$ of 74 respondents) stomped away after disagreements as if they, the nurses, were not worthy of any further comments (refer to: Figure 6). Nearly half of the respondents ( $44 \%$ of 79 respondents) reported cases of physicians having asked someone else to assist them although the nurses with whom they had had the disagreements, were capable and willing to help.

Misunderstanding of the role that nurses 


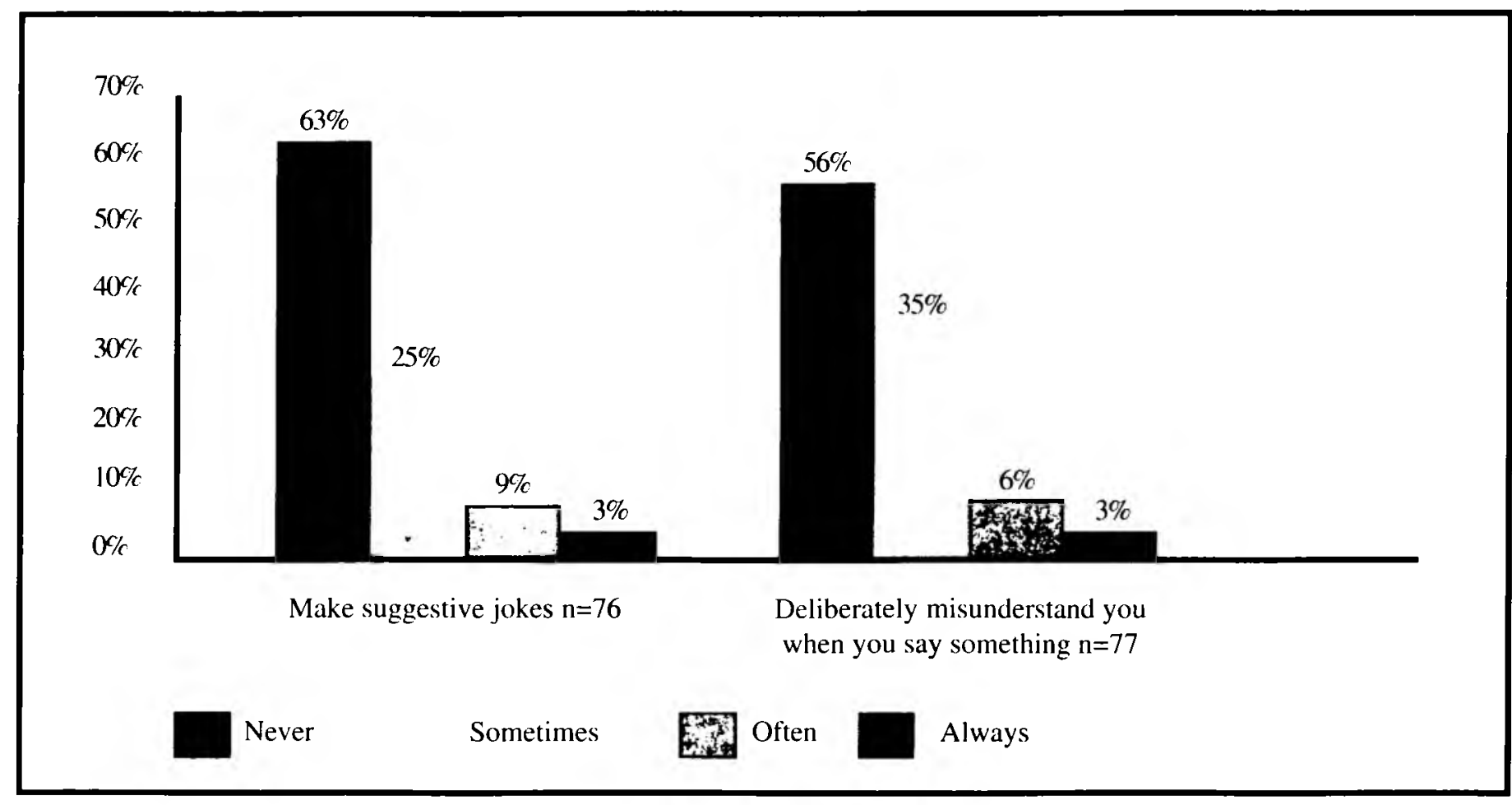

Figure 5 : Forms of indirect verbal abuse experienced by the participants

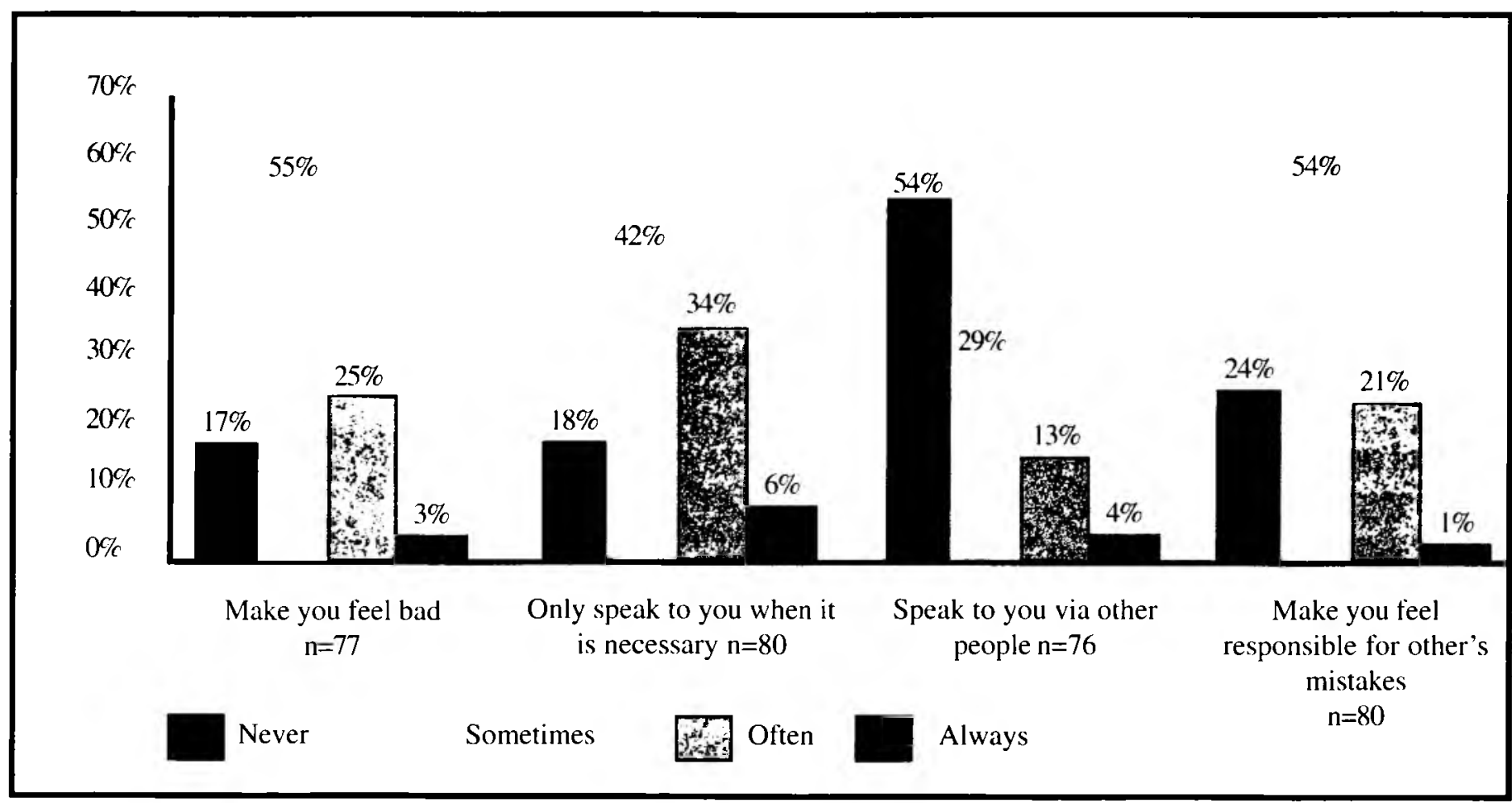

have in providing health care makes room for some physicians to decide whom they trust with the care that they have prescribed. Historically nurses were viewed as having had a nurturing role only and that their role was subservient to the role of the physician, who has been viewed as the professional person capable of prescribing care that the nurses had to implement. Although the role of nurses has changed over time, roleconflict still exists. Such a perception still leads to misunderstandings between the two professional groups that, unfortunately, may contribute to the perception that physicians can choose whom to work with, and whom to ignore.

\section{Identification of the physicians whom the respondents}

\section{considered as having abused nurses}

According to the answers of the respondents, $44(62 \%)$ of the 71 respondents who responded to the question indicated that, at the time of the investigation, more than one physician were involved in practices that they considered to be verbal abuse. Twelve of the respondents, out of the whole 


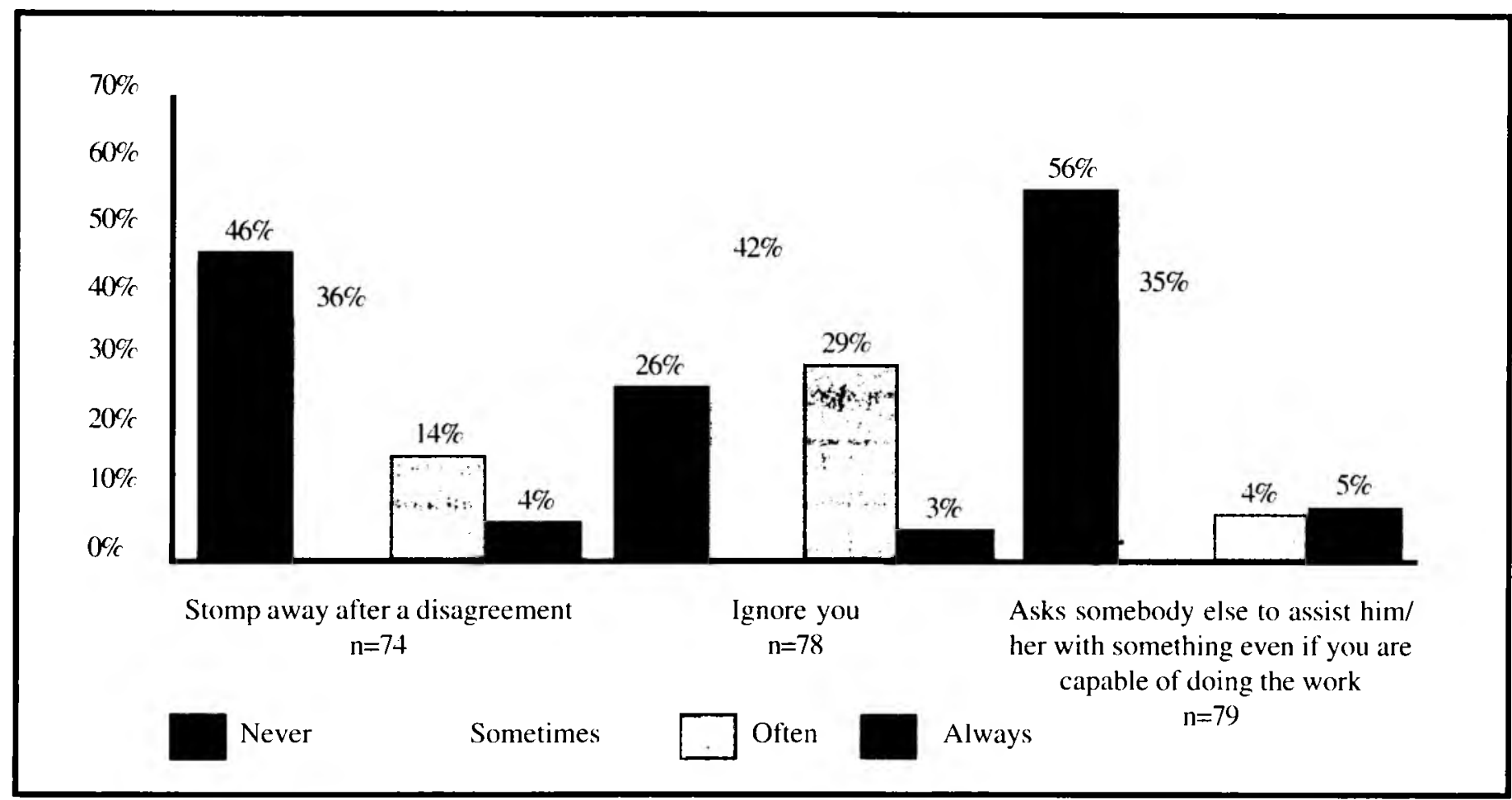

group of 83 , chose not to answer the question. This question was included due to the possibility that only one physician could have been involved and reported by several nurses, as physicians usually work in different units.

\section{Other forms of verbal abuse}

In the open-ended question, the respondents were given the opportunity to describe any other type of verbal abuse that took place that had not been covered by the structured questions. The comments did not reveal anything that had not been included in the questionnaire. However, it is clear that the nurses feel upset about the belittlement that they experience. One of them passed the comment that "...the physician tries to make you resign make life difficult for you".

\section{Summary of findings}

The majority of the respondents (79\%) experienced verbal abuse. Although all forms of verbal abuse were reported as having been experienced by the respondents, the highest percentages were allocated to:

- Being criticised even when they had not done anything wrong $(81 \%)$.

- $\quad$ Made to feel responsible for other people's mistakes (76\%).

- Having been the victim for physicians to vent their frustration on them $(81 \%)$.

- Having been screamed and shouted at in front of other people $(76 \%)$.

\section{Limitations of the research}

This descriptive study of perceptions and experiences of nurses of verbal abuse had been done in one private hospital only. The findings can therefore not be generalized and applied to other hospitals. The researcher therefore recommend that similar studies be done in other hospitals in both private and public sectors.

\section{Recommendations}

Based on the findings, it is recommended that:

- Protocols have to be developed for the prevention, reporting and dealing with verbal abuse. Nurses should be encouraged not to minimize incidents of verbal abuse and quietly accept them.

- Nurses should be taught how to deal with verbal abuse and should be encouraged to report threats or incidents of abuse to the hospital management.

- $\quad$ Colleagues and nursing managers should be encouraged to support nurses who report incidents.

\section{List of sources}

BEGANY, T 1995: Do you get the respect you deserve? (Physician's respect for nurses). Registered Nurse. 58(5):32-33.

COOK, JK, GREEN, J \& TOPP, RV 2001: Exploring the impact of physician verbal abuse on perioperative nurses. AORN Journal. 74(3):317-331.

COX, C 1991(a): Verbal abuse nationwide. Part I: Oppressed group behavior. Nursing Management. 22(2):3235.

COX, C 1991(b): Verbal abuse nationwide. Part II: Impact and modifications. Nursing Management. 22(3):66-69.

DIAZ, AL \& McMILIIN, J 1991: A definition and description of nurse abuse. Western Journal of Nursing Research. 13(1):97-109.

GEYER, N \& ZONDAGH, C 2002: Ethics, Law and complaints of unethical conduct. Nursing Update. 26(5):32-33.

INTERNATIONAL COUNCIL, OF NURSES 200(): Guidelines on coping with violence in the workplace. Geneva. 
1997: Creating a healthy work environment in the midst of organizational change and transition. JONA, 27(6):35-41.

LITTLE, L 1999: Risk factors for assaults on nursing staff. JONA. 29(12):22-29.

MANDERINO, MA \& BERKEY,N 1997:

Verbal abuse of staff nurses by physicians. Journal of Professional Nursing. 13(1):48-55.

UZUN, O 2003: Perceptions and experiences of nurses in Turkey about verbal abuse in clinical settings. Journal of Nursing Scholarship. 35(1):81-85.

WATSON, DS 2002: Disruptive behaviour and patient safety. AORN Joumal. 76(2):229-230. 